\title{
Influence of Vitamin A Consumption on Resting Metabolic Rate and Fasting Respiratory Quotient in Severely Obese Subjects
}

\author{
Radka Mikulová-Braunerová Vojtĕch Hainer Marie Kunešová \\ Jana Pařízková Š́rka Slabá Martin Wagenknecht \\ Obesity Management Center, Third Department of Medicine, Charles University, Prague, Czech Republic
}

Key Words

Retinoids · Obesity · Energy metabolism · Adipose tissue

\begin{abstract}
Objective: To study whether or not the amount of vitamin A consumed affects the resting metabolic rate (RMR) and fat oxidation at rest in severely obese subjects. Materials and Methods: In 239 obese subjects, RMR and fasting respiratory quotient (RQ) were determined by indirect calorimetry. Vitamin A consumption was calculated by the Czech PC program 'Nutrition'. The relation between the intake of vitamin A and RMR and RQ was tested by simple regression. High and low vitamin A consumers were defined by an upper and a lower quintile of vitamin A intake (>842 vs. <382 IU/day). Results: The RMR for high and low vitamin A consumers were 7,693.5 $\pm 1,557$ and $7,479.8 \pm 1,708 \mathrm{~kJ} /$ day, respectively, while the corresponding values for fasting $\mathrm{RO}$ were $0.800 \pm$ 0.077 and $0.809 \pm 0.049$, respectively. No significant correlation was found between vitamin $A$ consumption and both RMR and RO. Similarly, there was no significant difference in RMR and RQ, as well as weight, body mass index, body fat, waist girth and food quotient between the two groups characterized by high and low consumption of vitamin A. However, the energy intake of high
\end{abstract}

vitamin A consumers was significantly higher than that of low vitamin A consumers, due to higher carbohydrate and protein intake. Conclusion: There was no significant correlation between the vitamin A intake and RMR or RQ in obese subjects determined in this study.

Copyright $@ 2003$ S. Karger AG, Base

\section{Introduction}

Recent studies revealed that vitamin A could affect the regulation of fat stores by influencing adipocyte differentiation, thermogenesis and fat oxidation $[1,2]$. Vitamin A and its structural derivatives (retinoids) are involved in many important functions of the human organism, such as embryonic development, differentiation of epithelial and mesenchymal cells, hematopoiesis, reproduction and vision [3]. The main active metabolites are retinal and retinoic acid (RA). The former plays the key role in vision, and the latter mediates the other functions. RA is present in two isomers, all-trans RA and 9-cis RA, and acts via the activation of two types of nuclear receptors, RA receptors (RARs) and retinoid X receptors (RXRs). All-trans $\mathrm{RA}$ is a ligand for RAR, whereas 9-cis RA binds both RAR and $\operatorname{RXR}[1,4]$.

\section{KARGER \\ Fax +4161306 1234 \\ E-Mail karger@karger.ch \\ www.karger.com

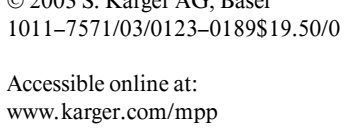

Dr. Radka Mikulová-Braunerová

Obesity Management Center, Institute of Endocrinology

Národni 8

CZ-116 94 Prague 1 (Czech Republic)

Tel. +420 224905 350, Fax +420 224905 325, E-Mail mikulova@email.cz 
Table 1. Characteristics of the subjects (means $\pm \mathrm{SD}$ )

\begin{tabular}{lccl}
\hline & \multicolumn{2}{l}{ Vitamin A } & \multirow{2}{*}{ p value } \\
\cline { 2 - 3 } & high consumers & low consumers & \\
\hline Subjects & 48 & 48 & \\
Age, years & $48.6 \pm 11.8$ & $42.9 \pm 11.7$ & 0.032 \\
Weight, $\mathrm{kg}$ & $114.5 \pm 22.4$ & $109.7 \pm 22.7$ & $\mathrm{NS}$ \\
BMI, $\mathrm{kg} / \mathrm{m}^{2}$ & $39.7 \pm 6.9$ & $39.5 \pm 7.7$ & $\mathrm{NS}$ \\
Body fat, $\mathrm{kg}$ & $57.5 \pm 14.7$ & $60.4 \pm 21.3$ & $\mathrm{NS}$ \\
FFM, $\mathrm{kg}$ & $56.5 \pm 15.8$ & $49.3 \pm 9.7$ & 0.017 \\
Waist circumference, $\mathrm{cm}$ & $118 \pm 17$ & $113 \pm 18$ & $\mathrm{NS}$ \\
\hline
\end{tabular}

BMI = Body mass index; FFM = fat-free mass.
In mammals, there are two different types of adipose tissue: white adipose tissue and brown adipose tissue. While white adipose tissue is involved in lipid storage, brown adipose tissue is the main site of non-shivering thermogenesis. Both types have been shown to take part in retinoid uptake, storage, mobilization and transport. Several studies revealed that RA induces the expression of the genes for uncoupling protein (UCP) $1[5,6]$ and UCP 3 [7]. These proteins are located in the inner mitochondrial membrane, act as protonophors and thus are able to uncouple oxidative processes of the respiratory chain from ATP synthesis. Retinoids may also stimulate the biochemical activity of UCPs, including that of UCP 2 expressed in white adipose tissue [8]. Therefore, they have been implicated in the regulation of energy metabolism.

RA has long been recognized as a potent inhibitor of adipocyte differentiation in several cell lines [9]. The effect depends on the retinoid concentration, the stage of the cell differentiation as well as the availability of retinoid receptors [10]. Because retinoids play a potential role in the regulation of fat stores and are possibly used in the treatment of obesity, we decided to study whether or not a relationship between the amount of vitamin A intake and resting metabolic rate (RMR) and fat oxidation at rest (evaluated by fasting respiratory quotient, RQ) exists in severely obese subjects.

\section{Subjects and Methods}

Subjects were recruited from patients who were referred to the Obesity Management Center of the Charles University, Prague, Czech Republic. We examined 239 severely obese subjects. The patients were divided into two groups of high and low vitamin A consumption, with an upper and a lower quintile of vitamin A intake of $>842$ and $<382$ IU/day, respectively. The average daily intake of vitamin $\mathrm{A}$ in the whole cohort was $670 \pm 430 \mathrm{IU} /$ day. We were not able to measure the vitamin A status in each patient as we were primarily concerned with daily intake.

Weight, body fat mass and fat-free mass were assessed by the bipedal bioimpedance method (TBF-105, Tanita, Tokyo, Japan) [11]. Anthropometrical measurements included waist circumference as a marker of body fat distribution. Open-circuit indirect calorimetry (Deltatrac ${ }^{\circledR}$, Datex, Helsinki, Finland) under basal conditions was used to determine the resting metabolic rate and RQ. The measurement was performed for $30 \mathrm{~min}$ in recumbent position after a 16hour overnight fast. Patients were asked to avoid smoking, caffeine intake and vigorous physical activity $24 \mathrm{~h}$ prior to indirect calorimetric measurement. The mean intraindividual coefficient of variation from repeated measurements was 3.0\% for RMR.

An average daily intake of energy, vitamin A, fat, carbohydrate and protein was calculated using the PC program 'Nutrition' which comprises about 2,500 food items of the Czech cuisine. The recorded 1-week dietary intake before the calorimetric examination was analyzed. However, the dietary records that were conducted three times during the 6-month period preceding the measurements exhibited similar results with regard to the energy and nutrient intake. The validity of the program used was confirmed by chemical analysis of vitamin A in ingested items. The food quotient (FQ), which is the theoretical RQ produced by the diet, was calculated from macronutrient intake expressed in percent according to the formula described by Toubro et al. [12]:

$\mathrm{FQ}=[0.207 \cdot$ carbohydrate $(\%)+0.159 \cdot$ fat $(\%)+0.193 \cdot$ protein $(\%)+0.137 \cdot$ alcohol $(\%)] /[0.207 \cdot$ carbohydrate $(\%)+0.226 \cdot$ fat $(\%)+0.243 \cdot \operatorname{protein}(\%)+0.206 \cdot \operatorname{alcohol}(\%)]$.

Statistical Analysis. Values are presented as means $\pm \mathrm{SD}$. The $\mathrm{t}$ test for unpaired data was used for comparing the two groups of subjects. $p<0.05$ was the threshold of significance.

\section{Results}

The essential characteristics (table 1) included age $(42.9 \pm 12.0$ years $)$, weight $(110.2 \pm 22.7 \mathrm{~kg})$, and body mass index $\left(39.1 \pm 7.5 \mathrm{~kg} / \mathrm{m}^{2}\right)$. The dietary and metabolic 
Table 2. Dietary and metabolic parameters of high and low vitamin A consumers (means $\pm \mathrm{SD}$ )

\begin{tabular}{lccl}
\hline & \multicolumn{2}{l}{ Vitamin A } & \multirow{2}{*}{ p value } \\
\cline { 2 - 3 } & high consumers & low consumers & \\
\hline RMR, kJ/day & $7,693.5 \pm 1,557$ & $7,479.8 \pm 1,708$ & NS $^{\mathrm{a}}$ \\
Fasting RQ & $0.800 \pm 0.077$ & $0.809 \pm 0.049$ & $\mathrm{NS}^{\mathrm{a}}$ \\
Energy intake, kJ/day & $6,741 \pm 2,912$ & $5,289 \pm 1,675$ & 0.0078 \\
Fat intake, g/day & $55.3 \pm 36.9$ & $43.3 \pm 30.5$ & $\mathrm{NS}$ \\
Carbohydrate intake, g/day & $212.1 \pm 82.1$ & $168.6 \pm 59.5$ & 0.008 \\
Protein intake, g/day & $64.2 \pm 22.8$ & $52.9 \pm 12.8$ & 0.008 \\
Food quotient & $0.872 \pm 0.024$ & $0.871 \pm 0.029$ & $\mathrm{NS}$ \\
\hline
\end{tabular}

a Adjusted for body composition and age. parameters are given in table 2. The RMR and fasting RQ were similar for both high and low vitamin A consumers. The difference was not significant, indicating no correlation between the intake of vitamin A and both RMR and RQ even after adjusting for age. (The correlation coefficient between vitamin A intake and, RMR and RQ was $0.081,0.084$, respectively). The body mass index, body fat, waist girth and food quotient were comparable in cohorts discordant with regard to the vitamin A intake although the high vitamin A consumers exhibited a significantly higher energy intake than low vitamin A consumers. The higher energy intake in this cohort was due to the higher intake of all three macronutrients. However, a significantly higher intake was demonstrated for carbohydrate and protein $(p=0.008)$. Surprisingly, the two groups of subjects did not differ significantly either in fat intake or in the RMR and the fasting RQ.

\section{Discussion}

Although we did not determine the vitamin A status in the volunteers, it has been demonstrated that a 24-hour recall of dietary intake is useful in evaluating the vitamin A status of a population, if the intake of food rich in vitamin A is infrequent [13].

Retinoids are reported to play an important role in the expression of several genes involved in the control of energy metabolism, but our results did not show that the amount of vitamin A consumed affects RMR and RQ in humans. This result could be due to inaccurate selfreports of dietary intake recorded by the subjects. However, the possible impact of retinoids on energy metabolism cannot be excluded. Although the higher vitamin A consumers exhibited a significantly higher energy intake, they were not more obese than the low vitamin A consumers. Therefore, there must be a factor preventing weight gain. A possible explanation could be the role of retinoids in diet-induced thermogenesis instead of resting energy expenditure. However, diet-induced thermogenesis was not studied.

\section{Conclusion}

The decrease in vitamin A intake observed during the long-term maintenance low-energy diet did not affect the RMR and fasting RQ in severely obese subjects. However, vitamin A may be involved in weight changes, but the underlying mechanism needs further investigation. 


\section{References}

1 Mandrup S, Lane MD: Regulating adipogenesis. J Biol Chem 1997;9:5367-5370.

2 Rabelo R, Reyes C, Shifman A, Silva JE: A complex retinoic acid response element in the uncoupling protein gene defines a novel role for retinoids in thermogenesis. Endocrinology 1996;137:3488-3496.

3 Olson JA: Vitamin A, retinoids and carotenoids; in Shils ME, Olson JA, Shike M (eds): Modern Nutrition in Health and Disease. Philadelphia, Lea \& Febiger, 1994, pp 287-307.

4 Villaroya F, Giralt M, Iglesias R: Retinoids and adipose tissues: Metabolism, cell differentiation and gene expression. Int $\mathrm{J}$ Obes Relat Metab Disord 1999;23:1-6.

5 Silva JE, Rabelo R: Regulation of the uncoupling protein gene expression. Eur J Endocrinol 1997; 136:251-264.

6 Alvarez R, De Andrés J, Yubero P, Viñas O, Mampel T, Iglesias R, Giralt M, Villaroya F: A novel regulatory pathway of brown fat thermogenesis. Retinoic acid is a transcriptional activator of the mitochondrial uncoupling protein gene. J Biol Chem 1996;271:31533-31542.
7 Nagase I, Yoshida S, Canas X, Irie Y, Kimura K, Yoshida T, Saito M: Upregulation of uncoupling protein 3 by thyroid hormone, peroxisome proliferator-activated receptor ligands and 9-cis retinoic acid in L6 myotubes. FEBS Lett 1999;461:319-322.

8 Rial E, Gonzalez-Barroso M, Fleury C, Iturrizaga S, Sanchis D, Jimenez-Jimenez J, Ricquier D, Goubern M, Bouillaud F: Retinoids activate proton transport by the uncoupling proteins UCP1 and UCP2. EMBO J 1999; 18:5827-5833.

9 Stone RL, Bernlohr DA: The molecular basis for inhibition of adipose conversion of murine 3T3-L1 cells by retinoic acid. Differentiation 1990;45:119-127.
10 Dani C, Smith AG, Dessolin S, Leroy P, Staccini L, Villageois $P$, Darimont C, Ailhaud G: Differentiation of embryonic stem cells into adipocytes in vitro. J Cell Sci 1997;110:12791285 .

11 Hainer V, Kunešová M, Par̆ízková J, S̆tich V, Hořejs̆ J, Müller L: Body fat assessment by a new biopedal bioimpendance instrument in normal weight and obese women. Sb Lek 1995 ; 96:249-256.

12 Toubro S, Sorensen TI, Hindsberger C, Christensen NJ, Astrup A: Twenty-four-hour respiratory quotient: The role of diet and familial resemblance. J Clin Endocrinol Metab 1998; 83:2758-2764.

13 Underwood BA, Olson JA: A Brief Guide to Current Methods of Assessing Vitamin A Status. International Vitamin A Consultative Group, International Life Sciences Institute, Nutrition Foundation ILSI Press, Washington 1993, pp 1-37. 